\title{
PENGEMBANGAN BAHASA ANAK USIA DINI MELALUI METODE BERCERITA DI LEMBAGA PAUD MERAJE GUNE
}

\author{
Supian Azhari \\ Program Pascasarjana UIN Sunan Kalijaga Yogyakarta \\ Email: azhari02091997@gmail.com
}

\begin{abstract}
Early Childhood Language Development Through Storytelling Method at Meraje Gune PAUD Institution. This paper will explore the methods used in learning to develop early childhood language skills at the Meraje Gune PAUD Institution. The focus of this research will be on how to develop language at an early age by using the storytelling method in improving language skills at an early age. The study uses descriptive qualitative research where one of the studies that describes the findings or results in the field, observes and analyzes what is in the research. The results of this study indicate that, early childhood language learning using methods that can develop the potential of early childhood language. In fact, the influence of learning methods in developing children's language skills is by opening access to improve children's language skills, seeing from starting to speak, never feeling shy in asking questions, being active in various fields, namely storytelling, singing and being a leader in class.
\end{abstract}

Key words: Language Development, Storytelling, Early Childhood.

Abstrak: Pengembangan Bahasa Anak Usia Dini Melalui Metode Bercerita Di Lembaga PAUD Meraje Gune. Tulisan ini akan menggali tentang metode bercerita yang digunakan dalam pembelajaran untuk mengembangkan kemampuan bahasa anak usia dini di Lembaga PAUD Meraje Gune. Fokus penelitian ini, akan mengkaji tentang bagaimana pengembangan bahasa anak usia dini dengan menggunakan metode bercerita dalam meningkatkan kemampuan bahasa anak usia dini. Penelitian menggunakan penelitian kualitatif deskriptif dimana salah satu penelitian yang mendeskripsikan temuan atau hasil yang ada dilapangan, mengamati dan menganalisa apa saja yang ditemukan dalam penelitian tersebut. Adapun hasil penelitian ini menunjukkan bahwa, pembelajaran kemampuan bahasa anak usia dini dengan menggunakan metode bercerita dapat mengembangkan potensi bahasa anak usia dini. Secara realitas, pengaruh metode pembelajaran dalam mengembangkan kemampuan bahasa anak usia dini dengan melalui metode bercerita bisa meningkatkan kemampuan bahasa anak, dilihat dari kelancaran berbicara, tidak pernah merasa malu dalam bertanya, aktif dalam berbagai bidang yaitu bercerita, bernyanyi dan menjadi pemimpin di kelas.

Kata Kunci: Pengembangan Bahasa, Bercerita, Anak Usia Dini.

\section{PENDAHULUAN}

Kemampuan bahasa merupakan salah satu pokok yang sangat penting yang harus diperhatikan oleh setiap pendidik, guna untuk mengoptimalkan panca indra terhadap anak baik dengan melalui apa 
Supian Azhari, Pengembangan Bahasa Anak Usia Dini Melalui Metode Bercerita Di Lembaga PAUD Meraje Gune

yang dilihat, didengar, dan dirasakan oleh anak itu sendiri. ${ }^{1}$ Kemampuan bahasa terhadap anak harus ditanamkan sejak usia dini karena pada fase tersebut anak akan cepat merespon apa yang dilihat, didengar dan dirasakan. Bahasa dikiaskan sebagai alat untuk menyampaiakan informasi terhadap orang lain, berkomunikasi, dan berintraksi. Apabila anak memiliki keterlambatan dalam mengembangkan bahasa maka akan berdampak terhadap perkembangan sosial dan psikologisnya terlebih akan merembet terhadap emosional anak. ${ }^{2}$.

Terkait dengan kemampuan bahasa anak usia dini yang sering terjadi dalam berbagai masalah yang dihadapi oleh anak ketika anak mengalami kesulitan dalam mengembangkan bahasa. Entah dengan faktor eksternal maupun faktor internal. Permasalahan ini sering terjadi ketika anak kurang diberikan perhatian yang lebih oleh guru maupun kluarganya, maka akibatnya anak itu sendiri akan mengalami keterlambatan dalam mengembangkan bahasanya dan sedikit mencerna apa yang dibicarakan oeleh teman sekitarnya sehingga menyebabkan anak tidak akan percaya diri dalam berbicara dan tidak berani berbicara ketika ditanya oleh siapapun. Sering kali juga kita ketahui gurunya selalu beranggapan bahwa dirinyalah sebagai wadah atau sumber ilmu pengetahuan. Akan tetapi tidak memperhatikan metode yang digunakan dalam mengajar tidak bervariasai atau bersifat konvensional dalam mengimplementasikan metode pembelajaran.

Brewer $^{3}$ Memberikan definisi tentang pengembangan bahasa merupakan alat yang digunakan untuk berkomunikasi antara sesama manusia yang baik melalui lisan, tulisan dan maupun lewat bahasa isarat.

\footnotetext{
${ }^{1}$ Anik Lestariningrum and Intan P.W, "Meningkatkan Kemampuan Bahasa Anak Usia Dini Melalui Media Panggung Boneka Tangan," Nusantara of Reseacrh 1 (2014).

2 Dwi Nami Karlina, "Meningkatkan Kemampuan Berbicara Anak Tk B Usia 5-6 Tahun Melalui Digital Storytelling Di Tk Apple Kids Salatiga Semester I Tahun Ajaran 2017/ 2018," JPUD - Jurnal Pendidikan Usia Dini 12, no. 1 (2018): 1-11, https://doi.org/10.21009//jpud.121.01.

${ }^{3}$ Hana Pebriana Putri, "Analisis Kemampuan Berbahasa Dan Penanaman Moral Pada Anak Usia Dini Melalui Metode Mendongeng," Obsesi Pendidikan Anak Usia Dini 1, no. 2 (2017).
} 
Hurlock $^{4}$ menjelaskan Bahasa merupakan pengucapan, pemikiran dan perasaan yang tersistem dan teratur yang digunakan dalam berkomunikasi anata seseorang yang terdiri dari menyimak, berbicara, membaca dan menulis. Darjowidjojo ${ }^{5}$ mengungkapkan pemahaman terhadap bahasa memiliki keterkaitan dengan kemampuan bahasa yang dilakukan anak secara natural pada waktu belajar bahasa Ibu. Dari berbagai pendapat dari para ahli bahasa dapat disimpulkan bahwa kemampuan bahasa merupakan alat untuk melakukan komunikasi dan berintraksi terhadap seseorang baik melalui lisan, tulisan, maupun perasaan yang tersistem dan teratur yang terdiri dari membaca, menyimak, menulis, dan berbicara sehingga memiliki keterkaitan dengan kemampuan belajar bahasa Ibu.

Dari berbagai permasalahan di atas peneliti tertarik utuk mengkaji problematika yang hendak dijawab secara signifikan "Yaitu bagaimana cara meningkatkan kemampuan bahasa anak melalui bercerita sambil bermain".? "Bagaimana langkah-langkah yang dilakukan oleh guru untuk mengoptimalkan pembelajaran bercerita sambal bermain sehingga bias meningkatkan kemampuan bahasa terhadap anak".? Maka dari itu peneliti ingin mengkaji lebih dalam lagi mengenai tentang Peningkatan Kemampuan Bahasa Anak Usia Dini dengan Bercerita Sambil Bermain yang akan dilakukan dalam penelitian lapangan di Lembaga PAUD. (Meraje Gune Desa Pejanggik Kecamatan Praya Tengah Kabupaten Lombok Tengah)

\section{METODE PENELITIAN}

Dalam penelitian ini menggunakan pendekatan metode kualitatif deskriftif yaitu menggambarkan atau mendiskripsikan sesuatu yang di

\footnotetext{
${ }^{4}$ Vivi Anggraini, Yulsyofriend Yulsyofriend, and Indra Yeni, "Stimulasi Perkembangan Bahasa Anak Usia Dini Melalui Lagu Kreasi Minangkabau Pada Anak Usia Dini," Pedagogi : Jurnal Anak Usia Dini Dan Pendidikan Anak Usia Dini 5, no. 2 (2019): 73, https://doi.org/10.30651/pedagogi.v5i2.3377.

${ }^{5}$ Salnita Yulia Eka, Atmazaki, and Abdurrahman, "Pemerolehan Bahasa Pada Anak Usia 3 Tahun," Jurnal Obsesi : Jurnal Pendidikan Anak Usia Dini 3 (2019).
} 
lapangan yang berdasarkan fakta-fakta yang ada yang biasa dilihat dalam objek penelitian, penelitian kualitatif menurut para ahli Cresswell, J. 19986. Cresswell $\mathrm{J}$, mendifinisikan kualitatif merupakan salah satu penelitian menghasilkan suatu penemuan yang tidak dapat dicapai dengan melalui statistik atau dengan cara lain dalam (pengukuran). Dimana dalam penelitian kualitatif digunakan sebagai penelitian yang menggambarkan suatu kehidupan yang ada terjadi di masyarakat, kelakuan, sosial dan prasejarah. Adapun dalam pengertian dari pendekatan deskriptif kualitatif merupakan salah satu penelitian yang hanya untuk mendeskripsikan yang terkait dengan permasalahan yang diteliti. Adapun subjek dari penelitian ini adalah mencari data sebanyak mungkin yang biasa dipercaya dalam memberikan titik terang suatu penelitian atau juga biasa disebut dengan sumber informasi data yang bertujuan untuk menghasilkan data yang cukup yang berkaitan dengan tujuan penelitian. Sasaran dalam penelitian ini adalah guru dan siswa yang ada di lembaga PAUD di KB. Meraje Gune. Dimana terdiri dari dua kelas (2) yaitu: kelas A dan kelas B di Lembaga tersebut. Akan tetapi dalam pengambilan sampel penelitian di kelas B terdiri dari 12 siswa yaitu (7) siswi perempuan dan (5) siswa lakilaki.

Sasaran dari penelitian ini adalah Guru dan Siswa yang ada di lembaga Pendidikan anak usia dini di KB Meraje Gune. PAUD Meraje Gune merupakan salah satu lembaga pendidikan anak usia dini yang terletak di Desa Pejanggik. Kecamatan Praya Tengah. Kabupaten Lombok Tengah. Provinisi Nusa Tenggara Barat (NTB.). Lembaga pendidikan ini bernama KB (PAUD) Meraje Gune.

Dan adapun tehnik pengumpulan data yang digunakan dalam penelitian ini adalah observasi, wawancara, dan dokumentasi.

\footnotetext{
${ }^{6}$ Rahmat Pupu Saeful, "Penelitian Kualitatif," Equilibrium 5 (2009).
} 
a) Observasi?

Obsevasi merupakan salah satu landasan dasar yang wajib dilakukan atau melaksanakan observasi ketika mengambil penelitian di lapangan atau di suatu Lembaga Pendidikan, observasi adalah catatan perilaku seseorang dalam suatu kejadian yang sistematis tidak melalui komunikasi seseorang yang ingin diteliti. Jadi observasi merupakan mengamati kegiatan dalam suatu proses atau objek dengan bermaksud memahami pengethuan dari sebuah fenomena-fenomena berdasarkan pengetahuan dan gagasan yang sudah diketahui sebelumnya dan bertujuan untuk mendapatkan sebuah informasi sebanyak mungkin yang dibutuhkan guna untuk melanjutkan sebuah penelitian. Jadi tujuan dari observasi ini adalah untuk mengetahui situasi kondisis yang ada di lapangan. Adapun yang di observasi dalam penelitian ini adalah: keberadaan sekolah dan memberikan surat untuk melakuakan sebuah penelitian.

b) Wawancara

Secara umum wawancara didefinisikan sebagai kegiatan pembicaraan atau percakapan yang dilakukan oleh dua orang atau lebih yang terdiri dari narasumber dan penanya, wawancara berguna untuk mengetahui suatu keadaan atau informasi yang terkait dengan masalah yang diteliti yang biasanya dilakukan dengan cara bertanya dari narasumber untuk meyakinkan bahwa masalah yang ditemukan di lapangan apakah sesui dengan hipotesis dari seorang peneliti. ${ }^{8}$. Mendefinisikan wawancara merupakan salah satu alat yang digunakan untu menggali informasi dengan melakukan berbagai pertanyaan baik dengan percakapan secara lisan untuk mengumpulkan data atau informasi.

\footnotetext{
7 Supomo Bambang and Indriantoro Nur, Metodologi Penelitian Bisnis (Yogyakarta: BFEE UGM, 2002).

${ }^{8}$ Margono, Metode Penelitian Pendidikan (Jakarta: Rineka Cipta, 1997).
} 
c) Dokumentasi

Dokumentasi merupakan salah satu cara untuk memperoleh data dan informasi dalam bentuk buku, arsif, dokumen, tentang pendapat teori-teori maupun gambar yang berupa laporan atau bukti yang mendukung dari jalannya suatu penelitian. Jadi dokumentasi dapat diartikan sebagai bukti yang mendukung jalannya suatu peneltian yang dapat berupa arsif, informasi, dokumen, dan gambar.

\section{KERANGKA TEORI}

\section{Pengembangan Kemampuan Bahasa Anak Usia Dini}

Dalam definisi pengembangan bahsa anak usia dini kata-kata dari perkembangan biasanya disandingkan dengan pertumbuhan dan kematangan anak, Chaplin mendefinisikan perkembangan adalah perubahan yang terjadi dalam diri organisme anak mulai dari sejak lahir sampai seterusnya sehingga sampai mendapatkan suatu perubahan perkembangan dan pertumbuhan jasmani sehingga munculnya kedewasaan. $^{9}$

Kemampuan bahasa terhadap anak berpengaruh terhadap tempat sosio psikologis atau lingkungan dari keluarganya ${ }^{10}$. Dimana dalam lingkungan keluarganya memiliki ikatan dalam suasana yang tercipta sangat harmonis, saling menjaga, saling membantu sosial dari keluarganya sanagat baik dengan anak akan sanagt mudah berintraksi dengan semua orang termasuk keluarganya. Skinner dalam Safitri, mendiskripsikan tentang perkembangan bahasa bagi anak usia dini dengan diawali dengan pengendalian dari luar diri anak, dengan ransangan yang diberikan melalui lingkungan, dengan adanya ransangan

\footnotetext{
9 Julrissani, "Karakteristik Perkembangan Bahasa Dalam Berkomunikasisiswa Sekolah," Edumaspul 4, no. 1 (2020): 72-87.

10 Yenny Safitri, "Faktor-Faktor Yang Berhubungan Dengan Perkembangan Bahasa Balita Di UPTD Kesehatan Baserah Tahun 2016," Jurnal Obsesi : Jurnal Pendidikan Anak Usia Dini 1, no. 2 (2017): 148, https://doi.org/10.31004/obsesi.v1i2.35.
} 
yang dimiliki oleh anak secara bertahap-tahap perkembangan bahasa anak akan menuju kesempurnaan. ${ }^{11}$

Dari berbagai definisi tentang pengembangan kemampuan bahasa anak usia dini dapat disimpulkn pengembangan kemampuan bahasa an ak merupakan suatu media yang digunakan untuk berintraksi dan berkomunikasi terhadap sesama manusia yang perlu diperhatikan agar sesuai dengan tingkat perkembangan dan pertumbuhan kemampuan bahasa anak usia dini sesuai dengan tahapannya.

a. Karakteristik Kemampuan Bahasa Anak Usia Dini

Karakteristik bahasa nak usia dini memiliki berbagai aspek pengembangan bahasa terhadap anak usia dini yang harus diperhatikan agar perkembangan bahasa anak usia dini berkembang sesuai dengan tahapannya. Adapun beberapa ahli mendiskripsikan karakteristik perkembangan bahasa anak usia yang berusia 5-6 tahun, adalah sebagai berikut: ${ }^{12}$

1. Anak sudah bisa mengucapkan 2600 kata-kata

2. Pengucapan kalimat anak sudah mencapai enam sampai beberapa kata

3. Anak bisa memahami kata-kata terdiri dari 20.000 kata

4. Anak sudah bisa berkomunikasi dengan jelas

5. Anak dapat menjelaskan kata-kata sederhana

6. Anak sudah bisa menggunakan kata-kata penghubuung, kata depan

7. Mengenal banya huruf dan dan anak usia 5-6 tahun sudah bisa mengekspresika diri, menulis, membaca, bahkan berpuisi.

Dari berbagai karakteristik pengmbangan kemampuan bahasa anak usia dini adapun berbagai tingkatan yang dicapai dalam perkembangan bahasa pada anak yang berusia 5-6 tahun yang telah disusun oleh BNSP yang sesuai dengan karakteristik kemampuan

11 Safitri.

12 Santrock J.W, Masa Perkembangan Anak, 11th ed. (jakarta: selemba humanika, 2011). 
pengembangan bahasa anak usia dini adalah sebagai berikut: ${ }^{13}$ (a) penyusunan kalimat dalam struktur yang lengkasp. (b). keterlibatan dalam pemilihan dan memutuskan segala aktivitas yang dilakukan Bersama temannya. (c). pembendaharaan kata lebih lengkap untuk melakukan komunikasi verbal.

b. Probelematika Kemampuan Bahasa Anak Usia Dini

Dari hasil penelitian yang dilakukan Mengenai tentang problematika keterlambatan berbicara dan gagap pada anak usia dini yang berusia 6 tahun, berdasarkan hasil penelitian yang dilakukan oleh Elsa dan kawan-kawannya yang langsung mewawancarai guru kelas yang ada di Lembaga tersebut mengenai tentang keterlambatan berbicara anak, dimana dalam berbicara anak itu suka mengulang suara atau suku kata terutama diawal seperti "da-da-dalem" nah hal semacam ini dikarenakan pada proses awal pembelajaran selalu d absen Gurunysa terkadang berbicara gagap juga terdengar Panjang seperti "sssssselalu" dan juga setelah jam pelajaran istirahat anak terkadang cendrung sendiri sehingga anak tidak melakukan berbicara sepenuhnya jadi pendiam. ${ }^{14}$.

Jadi dalam problematika di atas harus benar-benar diperhatikan oleh seorang guru agar tidak terjadi kesalahan yang patal seperti yang diderita oleh anak dan faktor kondisi lingkungan juga berpengaruh terhadap diri anak bukan hanya di lingkungan sekolah, akan tetapi dilingkungan keluarga juga harus benar-benar memperhatikan anaknya agar selalu mengajak berbicara, bermain dan sambil bercerita kepada anak. Maka perlu sekali membiasakan anak untuk berbicara semaunya dan biasakan anak berkomunikasi dan berintraksi dengan seluasnya agar tidak canggung dan gagap dalam

${ }^{13}$ Putri, "Analisis Kemampuan Berbahasa Dan Penanaman Moral Pada Anak Usia Dini Melalui Metode Mendongeng."

${ }^{14}$ Elisa Rahayu, Intan Widyaningsih, and Bayu Adi Laksono, "Problematika Keterlambatan Bicara Dan Gagap Pada Anak Usia 6 Tahun," Jurnal Pendidikan Modern 5, no. 2 (2020): 63-71, https://doi.org/10.37471/jpm.v5i2.73. 
berbicara terhadap semua orang supaya kemampuan bahasanya tidak terganggu.

\section{Metode Bercerita}

Metode bercerita merupakan ciri khas atau kebiasaan yang pernah dialami oleh siswa-siswi terdahulu sejak zaman kurikulum satuan Pendidikan 2006 (KTSP), hampir keseluruhan dari siswa-siswi terdahulu mengalami indahnya bercerita apalagi yang diceritakan sanagat berkesan oleh gurunya sampai tidak pernah lupa seumur hidupnya. Ya pada kesempatan itu guru seharusnya memfasilitasikan siswanya untuk diberikan kesempatan menceritakan kembali apa yang telah mereka alami sehingga bertujuan untuk mengarahkan sisiwa-siswinya menjadi suatu motivasi yang menghasilkan minat belajar mereka semakin besar untuk melatih kemampuan bahasa maupun menulis. ${ }^{15}$

Metode bercerita ini juga bisa membantu siswa-siswinya untuk melatih kemampuan dan keterampilan berbahasanya yang lancar dimana dengan menggunakan metode bercerita ini anak akan terbiasa berbicara dengan leluasa dan bisa mengembangkan kemampuan anak dalam melatih pemahaman, pelurusan pembendaharaan kata-kata dan tatabahasa serta dapat meningkatkan keterampilan dalam menyimak, mendengar, membaca dan menulis. ${ }^{16} 17$ Mendefinisikan metode bercerita merupakan bukan sekedsar membantu pengembangan kemampuan bahasa anak usia dini, akan tetapi metode bercerita ini juga bisa menciptakan minat dalam belajar anak, karena dalam tahapan perkembangan intelektual yang ke dua (2) yaitu praoprasional memberikan penjelasan mengenai

${ }_{15}$ Majid and Aziz Abdul, Mendidik Anak Lewat Cerita (jakarta: Mustaqiim, 2005).

${ }^{16}$ Sanjaya Arie, "Penerapan Metode Bercerita Dalam Mengembangkan Kemampuan Berbahasa Dan Karakter Peserta Didik Di Sekolah Dasar," IImiah Guru"COPE" 20 (2016).

17 Ni Wayan Nuraini, Lasmawan Wayan, and Sutama I Made, "Efektivitas Metode Bercerita Dengan Alat Peraga Tiruan Untuk Meningkatkan Kemampuan Berbahasa Dan Minat Belajar Anak Di Kelompok b Tk Barunawati," Program Pasca Serjana Universitas Ganesha 4 (2014). 
Supian Azhari, Pengembangan Bahasa Anak Usia Dini Melalui Metode Bercerita Di Lembaga PAUD Meraje Gune

perkembangan anak bahwa dalam diri anak juga mengalami proses asimilasi dimana anak memaksimalkan apa yang didengar, dilihat, dan dirasakan.

a. Implikasi Metode Bercerita Terhadap Perkembangan Anak Usia Dini

Dari beberapa definisi yang terkait dengan metode bercerita merupkan pengembangan bahasa yang di implementasikan kepada anak usia dini dalam meningkatkan kemampuan bahasa anak dengan kegiatan berbahasa yang bersifat produktif dalam hal ini menyertakan sebuah pemikiran, mental, keberanian, berkata yang jelas sehingga semua orang bisa memahami apa yang dibicarakan ${ }^{18}$. Akan tetapi dalam hal ini terdapat implikasi atau pengaruh metode bercerita bagi perkembangan bahasa anak usia dini adalah sebagai berikut:

a) Anak-anak bisa berintraksi deangan berabagai pembendaharaan kata-kata yang melibatkan proses kognitif anak

b) Dalam metode bercerita juga bisa membangun minat belajar anak dan melatih kepokusan/perhatian terhadap anak sehingga pemahaman dan perluasan kata-kata secara tata bahasa.

c) Menggunakan metode bercerita dalam mengembangkan bahasa anak usia dini juga bisa meningkatkan keterampilan anak untuk mendengarkan, menyimak, berbicara, dan menulis.

Dari ulasan di atas mengenai tentang implikasi atau pengaruh metode bercerita terhadap pengembangan bahasa anak usia dini dapat disimpulkan bahwa metode bercerita juga bukan hanya untuk mengembangkan kemampuan bahasa terhadap anak, akan tetapi metode bercerita juga bisa meningkatkan minat belajar anak sehingga dapat mengembangkan proses kognitif anak dan juga meningkatkan keterampilan anak mulai dari berbicara, mendengar, menyimak, dan menulis.

${ }^{18}$ Gana Kartinika Hadi, "Pengaruh Metode Bercerita Terhadap Kemampuan Mengungkapkan Bahasa Anak Usia 5-6 Tahun Di TK Pertiwi 1 Banjarsari," PG-PAUD Trunojoyo, Jurnal Pendidikan Dan Pembelajaran Anak Usia Dini 5 (2018). 
b. Manfaat Bercerita dalam mengembangkan kemampuan bahasa anak usia dini.

Adapun mamfaat dalam metode bercerita untuk meningkatkan kemampuan bahasa anak usia dini yang dikemukan oleh ${ }^{19}$ antara lain sebagai berikut:

a) Anak mendapatkan ilmu pengetahuan yang banyak

b) Diberikan pengalaman belajar yang menggembirakan dan mengesankan bagi anak

c) Metode bercerita juga sebagai media yang efektif untuk berkomunikasi

d) Mengasah kepekaan terhadap anak

Adapun mamfaat bercerita menurut Musfiroh $^{20}$ memberikan pernyataan dalam mamfaat metode bercerita terhadap perkembangan anak usia dini adalah sebagai berikut: a). membantu mengembangkan kepribadian moral anak. b). memberikan penyaluran terhadap imajinasi dan fantasi anak. c). memacu kemampuan verbal anak. d). memberikan ransangan terhadap anak agar minat belajarnya semakin tinggi. e). membuka cakrawala pengetahuan anak.

Jadi dalam mamfaat metode bercerita terhadap kemampuan bahasa anak dapad simpulkan bahwa dengan metode bercerita adalah salah satu metode yang efektif digunakan dalam pembelajaran anak usia dini di Lembaga PAUD, karena metode ini bisa memberikan ransangan terhadap anak untuk melakukan komunikasi dan berintraksi terhadap temannya guna untuk melancarkan berbicara terhadapanak itu sendiri.

\footnotetext{
${ }^{19}$ Annisa Amalia Rahmah, "Pengembangan Bahasa Anak Melalui Metode Bercerita Dengan Media Panggung Boneka Pada Anak Kelompok A Di Paud Al Farabi Cabean Mangunsari Salatiga Tahun Pelajaran 2018/2019" (IAIN SALATIGA, n.d.).

${ }^{20}$ Arie, "Penerapan Metode Bercerita Dalam Mengembangkan Kemampuan Berbahasa Dan Karakter Peserta Didik Di Sekolah Dasar."
} 


\section{HASIL PEMBAHASAN}

Adapun hasil dari penelitian yang dilakukan di lembaga PAUD Meraje Gune, dengan menggunakan penerapan metode bercerita dalam mengembangkan kemampuan bahasa anak usia dini. Berdasarkan hasil wawancara yang dilakukan oleh peneliti kepada Guru-Guru yang di Lembaga tersebut dengan berbagai pertanyaan yang sudah disiapkan oleh peneliti guna untuk menemukan jawaban yang bisa menjawab permasalahan di atas.

Dari hasil wawancara kepada kepada guru kelas "Ibuk Nurhasanah" mengenai tentang penerapan metode bercerita dalam pemaparannya dengan menggunakan metode tersebut anak snagat antusias sekali pada saat belajar dikarenakan lbuk Gurnya selalu bercerita tentang sejarah keislaman pada jaman dahulu dengan menggunakan media gambar dan buku cerita yang beranimasi sehingga menarik daya minat anak dalam belajar. Metode bercerita juga memberikan kesempatan anak untuk bertanya, berkomunikasi dan memberikan kesempatan anak untuk bercerita terkait apa yang dialami oleh anak tersebut. Dengan memberikan anak leluasa untuk bertanya maupun memberikan anak kesempatan untuk mencerikatan apa yang telah dialami oleh anak tersebut maka anak akan terbiasa berintraksi dan berkomunikasi dengan sesama guru maupun teman-temannyaa anak akan tidak merasa canggung dan malu ketika berhadapan dengan siapapun.

Hal ini senada dengan pendapat Rusniah Pemaparan mengenai tentang metode bercerita adalah tujuannya untuk melatih kemampuan berfikir terhadap anak, membantu perkembangan imajinasi dan fantasi terhadap anak, dan membuat susasana belajar yang menyenangkan di dalam kelas. ${ }^{21}$ Adapun tehnik yang dilakukan sama dengan "lbuk Guru

${ }^{21}$ Rusniah Rusniah, "Meningkatkan Perkembangan Bahasa Indonesia Anak Usia Dini Melalui Penggunaan Metode Bercerita Pada Kelompok a Di Tk Malahayati Neuhen 
Nurhasanah" yaitu dengan menggunakan bercerita melalui media buku dan gambar dengan menggunakan ilustrasi bermain peran dalam suatu cerita.

Dari ungkapan Ibuk Guru Zurriyatun bahwa metode bercerita adalah salah satu cara mengajar anak untuk memancing daya kosentrasi anak usai dini pada saat melakukan proses belajar-mengajar, dengan bercerita sambal bermain maka anak tidak akan mudah merasa bosen dalam belajar apalagi yang diceritakan masalah yang lucu-lucu yang disukai oleh anak. Dengan ini bisa membuat anak menjadi lebih bersamangat dalam belajr yang menyenangkan dsan menggembirakan. Mengajak anak dalam berintraksi dan berkomunikasi adalah salah satu cara yang digunakan oleh Guru di Lembaga PAUD ini ujar "Ibuk Guru Zurriyatun" guna untuk mengembangkan kemampuan bahasa anak. Memang pada saat inilah ditanamkan kemampuan bahasa anak sedikit demi sedikit kosa kata yang telah anak proleh seiring berjalannya waktu pertumbuhan dan perkembangan anak akan bertambah kosa kata yang dimiliki oleh anak tersebut.

"Bercerita bukan hanaya sekedar biasa terhadap anak" Ungkapan dari Ibuk Heriyanti S.Pd. selaku kepala sekolah yang ada di Lembaga Pendidikan anak usia din PAUD Meraje Gune desa pejanggik. Beliau memberikan ulasan mengenai tentang metode bercerita yang diterapkan di lembaganya tersebut. Bahwa metode bercerita juga harus memiliki persiapan yang sesuai untuk melakukan sebuah cerita kepada anak-anak. Dimana guru juga harus memahami terlebih dahulu apa yang ingin disampaikan yang sesuai dengan materi pembelajaran yang terkait dengan tema yang diceritakan, terkait dengan waktu yang tepat untuk melakukan sebuah cerita, dan suasana yang tepat adalah salah satu hal yang paling tepat untuk melakukan sebuah cerita. 
Supian Azhari, Pengembangan Bahasa Anak Usia Dini Melalui Metode Bercerita Di Lembaga PAUD Meraje Gune

Terkait dengan ungkapan dari lbuk Heriyanti tersebut senada dengan pemikiran dari Arie $^{22}$ dimana beliau Mendefinisikan metode bercerita juga membutuhkan kesipan terkait dengan pemilihan tema, pemilihan tema juga harus benar-benar diperhatikan oleh setiap Guru karena setiap jesenjangan usia anak itu memiliki tahapan-tahapan yang sesuai dengan cerita yang akan disampaiakn, misalnya anak yang berusia 4 tahun menyukai cerita dongeng nenek sihir dan anak nakal dan lain sebagaianya. Usia 4-6 tahun biasanya anak menyukai cerita tokoh-tokoh tentang kepahlawanan dan cerita. Jadi dalam hal ini Guru juga benarbenar cerdas untuk memilih tema dan waktu yang tepat untuk melakukan sebuah cerita dan sesuai dengan apa yang diminati oleh anak tersebut agar tidak mudah merasakan kebosenan dalam belajar.

Kegitan dalam bercerita dinilai oleh guru untuk mengetahui perkembangan bahasa anak usia dini. Berikut kompilasi penilaian kemampuan bahasa anak di Lembaga Pendidikan PAUD Meraje Gune:

Table : 1 Kompilasi Data Bulanan Hasil Karya Anak

Nama : Rendi

Bulan : November

\begin{tabular}{|c|c|c|c|c|c|c|}
\hline Asfek & $\begin{array}{c}\text { Kompetensi } \\
\text { dan Indikator }\end{array}$ & M1 & M2 & M3 & M4 & $\begin{array}{c}\text { Hasil } \\
\text { Akhir }\end{array}$ \\
\hline Bahasa & $\begin{array}{c}\text { Menceritakan } \\
\text { kegiatan yang } \\
\text { sudah } \\
\text { dilakukan }\end{array}$ & MB & BSH & BSB & BSB & BSB \\
\hline
\end{tabular}

Terkait hasil dalam penilaian table diatas dapat disimpulkan bahwa siswa yang bernama Rendi dalam aspek perkembangan bahasa dengan indicator menceritakan kegiatan yang sudah dilakukan memiliki hasil penilaian dalam minggu pertama mulai berkembang (MB), minggu kedua berkembang sesuai harapan $(\mathrm{BSH})$, minggu ketiga dan keempat berkembang sangat baik (BSB), dalam hasil akhir mendapatkan nilai berkembang sangat baik (BSB).

${ }^{22}$ Arie, "Penerapan Metode Bercerita Dalam Mengembangkan Kemampuan Berbahasa Dan Karakter Peserta Didik Di Sekolah Dasar." 
Setelah guru menila hasil perkembangan bahasa selama 6 bulan kemudian guru mengkompilasikan penilain semester. Dalam penilaian semester meliputi nama sisiwa usia, program pengembangan, kompetensi dasar, indicator, simpulan bulan 1,2,3,4,5,6, dan simpilan umum.

Table: 2 Kompilasi Data Semester 1 Tahun 2020

Nama : Rendi

Usia : 5 Tahun

\begin{tabular}{|c|c|c|c|c|c|c|c|c|c|}
\hline $\begin{array}{c}\text { Program } \\
\text { Pengem } \\
\text { bangan }\end{array}$ & KD & $\begin{array}{c}\text { INDIKA } \\
\text { TOR }\end{array}$ & $\begin{array}{c}\text { SIMP. } \\
\text { BLN } \\
1\end{array}$ & $\begin{array}{c}\text { SIMP. } \\
\text { BLN } \\
2\end{array}$ & $\begin{array}{c}\text { SIMP. } \\
\text { BLN } \\
3\end{array}$ & $\begin{array}{c}\text { SIMP. } \\
\text { BLN } \\
4\end{array}$ & $\begin{array}{c}\text { SIMP. } \\
\text { BLN } \\
5\end{array}$ & $\begin{array}{c}\text { SIMP. } \\
\text { BLN } \\
6\end{array}$ & $\begin{array}{c}\text { SIMPUL } \\
\text { AN } \\
\text { UMUM }\end{array}$ \\
\hline Bahasa & 4.11 & $\begin{array}{c}\text { Mencerit } \\
\text { akan } \\
\text { kegiatan } \\
\text { yang } \\
\text { sudah } \\
\text { dilakukn }\end{array}$ & BSH & BSH & BSB & BSB & BSB & BSB & BSB \\
\hline
\end{tabular}

Dilihat dari table di atas dapat disimpulkan bahwa program pengmbangan bahasa anak usia dini dengan indicator menceritakan kegiatan yang sudah dilakukan. Dalam hasil nilai sisiwa yang bernama Rendi mendapat nilai kompilasi satu semester yaitu berkembangan sangat baik (BSB).

\section{KESIMPULAN}

Dari berbagai ulasan di atas mengenai hasil dari wawancara yang telah dilaksanakan oleh peneliti kepada Guru yang ada dilembaga PAUD Meraje Gune. Meningkatkan kemampuan perkembangan bahasa anak usai dini dengan menggunakan metode bercerita dalam hasil penelitian yang telah dilakukan oleh peneliti bahwa dengan menggunakan metode bercerita bisa meningkatkan kemampuan perkembangan bahasa anak usia dini. Dilihat dari aktivitas berbicara anak dalam keseharian, keberanian anak untuk menceritakan pengalamannya, dan tidak mersa malu terhadap siapapun Ketika di ajak berbicara. 


\section{DAFTAR PUSTAKA}

Anggraini, Vivi, Yulsyofriend Yulsyofriend, and Indra Yeni. "Stimulasi Perkembangan Bahasa Anak Usia Dini Melalui Lagu Kreasi Minangkabau Pada Anak Usia Dini." Pedagogi: Jurnal Anak Usia Dini Dan Pendidikan Anak Usia Dini 5, no. 2 (2019): 73. https://doi.org/10.30651/pedagogi.v5i2.3377.

Arie, Sanjaya. "Penerapan Metode Bercerita Dalam Mengembangkan Kemampuan Berbahasa Dan Karakter Peserta Didik Di Sekolah Dasar." IImiah Guru"COPE" 20 (2016).

Bambang, Supomo, and Indriantoro Nur. Metodologi Penelitian Bisnis. Yogyakarta: BFEE UGM, 2002.

Eka, Salnita Yulia, Atmazaki, and Abdurrahman. "Pemerolehan Bahasa Pada Anak Usia 3 Tahun." Jurnal Obsesi : Jurnal Pendidikan Anak Usia Dini 3 (2019).

Hadi, Gana Kartinika. "Pengaruh Metode Bercerita Terhadap Kemampuan Mengungkapkan Bahasa Anak Usia 5-6 Tahun Di TK Pertiwi 1 Banjarsari." PG-PAUD Trunojoyo, Jurnal Pendidikan Dan Pembelajaran Anak Usia Dini 5 (2018).

J.W, Santrock. Masa Perkembangan Anak. 11th ed. jakarta: selemba humanika, 2011.

Julrissani. "Karakteristik Perkembangan Bahasa Dalam Berkomunikasisiswa Sekolah." Edumaspul 4, no. 1 (2020): $72-$ 87.

Karlina, Dwi Nami. "Meningkatkan Kemampuan Berbicara Anak Tk B Usia 5-6 Tahun Melalui Digital Storytelling Di Tk Apple Kids Salatiga Semester I Tahun Ajaran 2017/ 2018." JPUD - Jurnal Pendidikan Usia Dini 12, no. 1 (2018): 1-11. https://doi.org/10.21009//jpud.121.01.

Lestariningrum, Anik, and Intan P.W. "Meningkatkan Kemampuan Bahasa Anak Usia Dini Melalui Media Panggung Boneka Tangan." Nusantara of Reseacrh 1 (2014).

Majid, and Aziz Abdul. Mendidik Anak Lewat Cerita. jakarta: Mustaqiim, 2005.

Margono. Metode Penelitian Pendidikan. Jakarta: Rineka Cipta, 1997.

Nuraini, Ni Wayan, Lasmawan Wayan, and Sutama I Made. "Efektivitas Metode Bercerita Dengan Alat Peraga Tiruan Untuk Meningkatkan Kemampuan Berbahasa Dan Minat Belajar 
Anak Di Kelompok b Tk Barunawati." Program Pasca Serjana Universitas Ganesha 4 (2014).

Putri, Hana Pebriana. "Analisis Kemampuan Berbahasa Dan Penanaman Moral Pada Anak Usia Dini Melalui Metode Mendongeng." Obsesi Pendidikan Anak Usia Dini 1, no. 2 (2017).

Rahayu, Elisa, Intan Widyaningsih, and Bayu Adi Laksono. "Problematika Keterlambatan Bicara Dan Gagap Pada Anak Usia 6 Tahun." Jurnal Pendidikan Modern 5, no. 2 (2020): 63-71. https://doi.org/10.37471/jpm.v5i2.73.

Rahmah, Annisa Amalia. "Pengembangan Bahasa Anak Melalui Metode Bercerita Dengan Media Panggung Boneka Pada Anak Kelompok A Di Paud Al Farabi Cabean Mangunsari Salatiga Tahun Pelajaran 2018/2019." IAIN SALATIGA, n.d.

Rusniah, Rusniah. "Meningkatkan Perkembangan Bahasa Indonesia Anak Usia Dini Melalui Penggunaan Metode Bercerita Pada Kelompok a Di Tk Malahayati Neuhen Tahun Pelajaran 2015/2016." JURNAL EDUKASI: Jurnal Bimbingan Konseling 3, no. 1 (2017): 114. https://doi.org/10.22373/je.v3i1.1445.

Saeful, Rahmat Pupu. "Penelitian Kualitatif." Equilibrium 5 (2009).

Safitri, Yenny. "Faktor-Faktor Yang Berhubungan Dengan Perkembangan Bahasa Balita Di UPTD Kesehatan Baserah Tahun 2016." Jurnal Obsesi: Jurnal Pendidikan Anak Usia Dini 1, no. 2 (2017): 148. https://doi.org/10.31004/obsesi.v1i2.35. 